FEDERICO FERRETTI - BA, MA, PhD, Associate Professor, University College Dublin, School of Geography, Belfield, Newman Building, Room H015, federico.ferretti@ucd.ie, http://www.ucd.ie/research/people/geography/drfedericoferretti/; tel. +3531 716 8176, +39 340 4944825; ORCID ID: 0000-0002-5446-6522; Scopus: 55540917000

\title{
Decolonising the Northeast: Brazilian subalterns, non-European heritages and radical geography in Pernambuco
}

Abstract: This paper addresses histories and geographies of the Northeast of Brazil in the works of radical Pernambuco geographer Manuel Correia de Andrade and his main intellectual inspirations, such as Euclides da Cunha and Josué de Castro. Drawing upon current literature on subaltern spaces, critical race studies and the Modernity-ColonialityDecoloniality project, I especially consider de Andrade's works that address popular revolts by marginalised and racialised groups in Brazilian history, including the plurisecular saga of Black slaves' quilombos and their role in the abolition of slavery, as well as the formation of Brazilian territories. My main argument is that the marginalised groups analysed in these works, similar to more studied cases such as Haiti's revolutionaries, provided examples of subaltern agency and resistance by taking their freedom by themselves, through direct action, without waiting for legitimation from their European counterparts. Subaltern spaces, intended as spaces of resistance, are key to understanding these movements. The fact that members of the radical circuits of Brazilian and Pernambucan geography in the second half of the twentieth century showed awareness of what today is called the coloniality of power and colonial difference accounts for the effectiveness of studying linguistically and culturally different geographical traditions to decolonise (Western and English-speaking) academia.

F. Ferretti, 2019 "Decolonising the Northeast: subalterns, non-European heritages and radical geography in Pernambuco", Annals of the American Association of Geographers [early view] https://www.tandfonline.com/doi/full/10.1080/24694452.2018.1554423 
Keywords: Northeast of Brazil; Decolonial turn; Subaltern space; Quilombos; Alternative geographical traditions

This paper contributes to the ongoing rediscovery of a radical geographical tradition from North-eastern Brazil in the twentieth century (Carter 2018; Davies 2018; Melgaço 2017; Melgaço and Prouse 2017; Ferretti 2018 and 2019; Ferretti and Viotto 2018) by analysing works of its main representatives that address non-European (indigenous, Afro-Brazilian and caboclo) geographies of their region, with a special focus on histories of resistance to colonisation, slavery and land exploitation by European and Brazilian elites. While the authors mentioned above have shown that the works of these geographers were mutually connected and benefited from shared international scholarly networks identifying, among others, the three key figures of Milton Santos (1926-2001), Josué de Castro (1908-1973) and Manuel Correia de Andrade (1922-2007), I focus especially on the latter's works. De Andrade's international networks were the object of recent investigation (Ferretti 2018), and his legacy still attracts a certain attention in Brazilian scholarship (Viotto 2017), being also used as reference for Pernambucan histories (Mosher 2008). Nevertheless, de Andrade remains the lesser known of these geographers in international scholarship, in part because only one of his numerous books, The Land and People of Northeast Brazil, was translated into English (Andrade 1980). Therefore, there is an urgent need to rediscover these contributions and make them known to international scholarship for their potentiality to engage with wider debates.

F. Ferretti, 2019 "Decolonising the Northeast: subalterns, non-European heritages and radical geography in Pernambuco", Annals of the American Association of Geographers [early view] https://www.tandfonline.com/doi/full/10.1080/24694452.2018.1554423 
In analysing this body of work, I draw upon ideas on subaltern spaces and subaltern geographies recently elaborated by geographers (Clayton 2011; Gidwani 2009; Jazeel 2014; Legg 2016; Davies 2017), on critical race studies involving historical and cultural geographers (Bressey 2011; Nash 2003; Anderson 2008), and, more broadly, on interdisciplinary scholarship addressing subaltern identities and Black solidarity networks across Atlantic and Pacific worlds (Gilroy 1993; Featherstone 2013, Linebaugh and Rediker 2000; Shilliam 2015). According to Dan Clayton, a polysemic and relational notion of subaltern space addresses "issues of subordination and oppression, and their relation to questions of voice, agency, representation, situated knowledge and imagined community" (Clayton 2011, 246). This notion especially can be referred to what Dipesh Chakrabarty called the "non-industrial revolutionary subject" (Clayton 2011, 248), breaking the schemes of historicism. The first definitions of the concept of "subaltern" by authors such as Antonio Gramsci and later Ranajit Guha were famously questioned by Gayatri Spivak, arguing that "the subaltern cannot speak" (Spivak 1988, 308), given that these subjects hardly could have a direct voice beyond the mediation of sympathetic or organic intellectuals. Indeed, nonelites are seldom represented in the archives (Legg 2016). Clayton's first definition of subaltern space as a "differential" one can match the cases addressed by de Andrade and other North-eastern radical geographers, namely, Black, caboclo and indigenous communities, in their declination as a "resistant and anticipatory space within the past and the present, from which ... domination will or can be subverted and overturned" (Clayton 2011, 249).

Critical geographies consider race as a cultural rather than biological issue and, although denunciations on the underrepresentation of non-White persons and other minorities in academia are a very important part of critical studies (Esson et al., 2017), most authors argue

F. Ferretti, 2019 "Decolonising the Northeast: subalterns, non-European heritages and radical geography in Pernambuco", Annals of the American Association of Geographers [early view] https://www.tandfonline.com/doi/full/10.1080/24694452.2018.1554423 
that the problem with present-day society no longer is mere biological racism but instead several forms of cultural essentialism that naturalize the antagonism between different social groups (Nash 2003). An important author in critical race studies, Robbie Shilliam, addresses Afro-Caribbean cultures as a reservoir of "uncolonised" social and cultural practices, such as Voodoo in Haiti and the Rastafarian religion in Jamaica and Eastern Caribbean, to upset Western and colonial epistemes. For Shilliam, decolonising knowledge and defining the conditions where subalterns can speak implies "a critical retrieval of marginalized cosmologies and delegitimized epistemes that might provide a keener insight and set of alternatives to present-day iniquitous global power structures" (Shilliam 2012, 332). Among these "otherwise epistemes", Shilliam identifies traditions that African slaves carried with them in the New World, resulting in the subversive and resistant potential for the "redemption" (Shilliam 2012, 338) of the Rastafari religion.

Analysing the case that unanimously is considered as the archetypical example of Afrodescendant slaves taking their freedom by themselves, eventually the Haitian revolution and its "Black Jacobins" (James 1938), Shilliam observes how "colonial science seeks to segregate peoples from their lands, their pasts, their ancestors, spirits and agencies" (Shilliam 2017, 276), all factors that inspired resistance against masters and colonisers. Therefore, for Shilliam, considering other-wise cosmologies and epistemes allows understanding maroon and resistant communities as characterised by a subversive "quotidian living together - a seminal relationality, rather than the genocidal segregation of plantation slavery" (Shilliam 2017, 288). For Shilliam, and for authors such as Susan Buck-Morss (2009), stories such as those of the first Haitian Constitution show that ideas such as democracy and emancipation are not European, Western or White prerogatives.

F. Ferretti, 2019 "Decolonising the Northeast: subalterns, non-European heritages and radical geography in Pernambuco", Annals of the American Association of Geographers [early view] https://www.tandfonline.com/doi/full/10.1080/24694452.2018.1554423 
Subaltern geographies and critical race studies often are associated with the Latin American collective Modernity-Coloniality-Decoloniality (MCD), whose most famous exponent in Brazilian geography, Carlos Walter Porto-Gonçalves, worked with Santos and participated along with de Andrade in rescuing Josué de Castro's intellectual legacy (Mançano-Fernandes and Porto-Gonçalves 2007). Drawing upon the contributions of other leading figures of the “decolonial turn”, such as Walter Mignolo, Enrique Dussel and Anibal Quijano, and their ideas in the geopolitics of knowledge and colonial difference, Porto-Gonçalves argues that Latin America is a geopolitical concept, one that was inaugurated in the nineteenth century in the context of French-British imperial rivalries to state the proximity of neo-decolonised Latin American states with a "Latin" power such as France. However, from a decolonial perspective, the main issue with this definition is that it completely erases non-European cultures, namely, indigenous and African identities. This results in the continuity of internal colonialism, a phenomenon still fostered by the extractivism of states and big corporations grabbing the lands of peasant and indigenous communities (Porto-Gonçalves and Araújo Quental 2012).

Mignolo likewise argues for an epistemic decolonisation drawing upon different thoughts from European concepts. Criticising mainstream postmodern and constructivist lines of thinking that he deems "eurocentric critiques of eurocentrism", Mignolo considers MCD's inspirations: "Individual thinkers and activists like Waman Puma de Ayala in colonial Peru, Ottobah Cugoano, in British Caribbean and then in London, in the eighteen century; Mahatma Gandhi in nineteenth-twentieth century India; Amilcar Cabral in the Portuguese colonies of Africa; Aimé Césaire and Frantz Fanon in the French Caribbean; W.E.B. Dubois and Gloria Anzaldúa in the US ... countless uprising and social movements that, today, have in the Zapatistas and

F. Ferretti, 2019 "Decolonising the Northeast: subalterns, non-European heritages and radical geography in Pernambuco", Annals of the American Association of Geographers [early view] https://www.tandfonline.com/doi/full/10.1080/24694452.2018.1554423 
the indigenous movements in Ecuador, Bolivia as well as Indigenous activists in New Zealand, Australia, Canada and the US" (Mignolo 2010, 16). This list naturally comprises "the 1804 Haitian revolution" (Escobar 2010, 36) and its leader, Toussaint Louverture.

In the construction of what Dussel defines as a nonintrinsically European discourse (Dussel 2013), an important decolonial argument is the idea of the coloniality of power, positing that coloniality "is still the most general form of domination in the world today, once colonialism as an explicit political order was destroyed" (Quijano 2010, 25) and recalling de Castro’s and de Andrade's ideas on the continuity between the colonial past and the lasting social problems of the Brazilian Northeast. Similar to cultural geographers like Nash, MCD authors consider that biological notions of race were functional to discourses of European colonialism to set domination as "a relationship of biologically and structurally superior and inferior" (Quijano 2010, 25). Finally, Ramón Grosfoguel's concept of "pluriversality” argues to avoid colonial and postcolonial essentialisms at the same time to work for a pluralistic dialogue, aware of the complexity of domination's relationships (Grosfoguel 2008). Further reflection is needed on the place of Brazil in this movement, which is arguably more populated by scholars from Hispanic America than by Brazilians: paradoxically, works by key MCD authors are more likely to be routinely translated into English than into Portuguese. While a full account of this phenomenon goes beyond the scope of this paper and relates to wider cultural and political differences between Lusophone and Spanish-speaking scholarship, it is possible to argue that more work is needed on what Porto-Gonçalves defines as the coloniality of Brazilian identities. There, stereotypes such as "the North-eastern, the Northern or the Southern [person]" (PortoGonçalves 2005, 3) are essentialised, without producing the same caricature for the identities

F. Ferretti, 2019 "Decolonising the Northeast: subalterns, non-European heritages and radical geography in Pernambuco", Annals of the American Association of Geographers [early view] https://www.tandfonline.com/doi/full/10.1080/24694452.2018.1554423 
of those from other regions considered more "central". The present work is also an attempt to fill this Brazilian lacuna, at least at the level of international scholarship.

This paper's main argument is that these radical Brazilian geographers showed an early awareness in the centrality of the colonial problem in their analysis of the Northeast's social problems, by addressing them in the context of lasting colonial legacies and by arguing that, in their region, subalterns took their own rights through direct action and spoke through their historical autonomous praxes rather than through archives and discourses. Their revolts primarily claimed land, which was and still is the crux of Brazilian social movements for agrarian reform. De Andrade and colleagues gave special emphasis to the role of subaltern agency by marginalised and racialised groups, drawing upon a militant perspective in establishing links between past and present to support the ongoing struggles of landless peasants and marginalised social groups, whose political relevance in the present is perceived clearly by Brazilian scholarship (Almeida 2010). This was especially the case with de Andrade's works on Brazilian quilombos and the struggles for the abolition of slavery, on the history of popular revolts in nineteenth century Pernambuco and Alagoas, and on the lasting of colonial legacies in the agrarian problems of the Northeast. These works can account for a neglected radical geographical tradition from South America, and especially from Northeastern Brazil, which can nourish today debates on how geography addresses Black, indigenous and subaltern studies, and how to decolonise geography (Legg 2017; Radcliffe 2017). This should be done by considering voices from outside the global north, and especially from outside English-speaking academia.

F. Ferretti, 2019 "Decolonising the Northeast: subalterns, non-European heritages and radical geography in Pernambuco", Annals of the American Association of Geographers [early view] https://www.tandfonline.com/doi/full/10.1080/24694452.2018.1554423 
De Andrade traced two main parallels between Brazilian subaltern histories and later political and social struggles: the comparison between the nineteenth-century Cabanada revolt in Pernambuco and the contemporary Movimento dos Trabalhadores Rurais Sem Terra-MST (Almeida 2010), and the continuity between historical struggles for the abolition of slavery and the unfinished business of agrarian reform in Brazil (Rodrigues 2008). Without being "postcolonial" or "postmodern" scholars, de Andrade and his closest colleagues such as de Castro questioned colonial modernity by denouncing the past and present weight of the coloniality of power in their region and by valuing African and indigenous traditions and practices (Ferretti 2019). Recent works confirm that praxes of direct action in Latin American social movements come more from this subaltern tradition than from big ideologies of European importation (Souza 2016; Stahler-Sholk, Vanden and Becker 2014; Zibechi 2010), although references to radical European authors, especially anarchists and Marxists, were not rare in de Andrade's work, as I explain below.

De Andrade's idea of an intersection between social and racial exclusion paralleled the works of Brazilian anthropologist Darcy Ribeiro (1922-1997), who questioned Brazilian national myths on "racial democracy", arguing that such democracy is an illusion, due to the lasting of “deep abysses separating the social strata" (Ribeiro 2000, 5). In Brazilian society, inequalities continue to penalise mostly communities of indigenous and African descent. Conversely, de Andrade's views of the specific historical roles played by Indigenous and Afro-Brazilians could hardly match some of Ribeiro's views positing a certain uniformity of Brazil. For Ribeiro, the processes of miscegenation which followed the Conquest produced a "new people", that is a "macro-ethnicity' on which isolated tribal groups have lost importance" (Ribeiro 2000, 2). De Andrade's views can be better explained through the idea of mistura

F. Ferretti, 2019 "Decolonising the Northeast: subalterns, non-European heritages and radical geography in Pernambuco", Annals of the American Association of Geographers [early view] https://www.tandfonline.com/doi/full/10.1080/24694452.2018.1554423 
(mixing-up) deployed by João Pacheco de Oliveira. Complementing the famous works of anthropologists who addressed the (genuinely or allegedly) "untouched" Amazonian indigenous communities such as Pierre Clastres and Eduardo Viveiros, Oliveira argues that the specificity of North-eastern indigenous populations is their early contact and integration with the Europeans and Africans who arrived in the region in large numbers from the sixteenth century. This early miscegenation and transculturation was the reason for which ethnographers long overlooked North-eastern Indios, whose cultures were considered not "pure" enough to interest their studies. Yet, Oliveira observes a recent "journey back" (Oliveira 2010, 26) of both indigenist activism and scholarship to rescue the memory and the present life of several dozens of indigenous ethnic groups previously not "inventoried". Formerly an ideological device to produce uniformity, the idea of mistura is now an important notion for North-eastern indigenous communities, committed to "denaturalising the mistura as the only way to survive and become citizens" (Oliveira 2010,18). This means acknowledging the historical nature of mixing-up processes to conserve both cultural specificities and to claim for full social and political rights.

This rebuttal of an idealised "authenticity" or "purity" also matches the concept of hybridization proposed by Néston García Canclini, which is intended to "remove support from policies of fundamentalist homogenization or the limited (segregated) recognition of 'the plurality of cultures"” (García Canclini 2005, xxix). For García Canclini, hybridization is a notion which encompasses the ideas of mestizaje, syncretism and creolization and should be considered as a "foundational process in the societies of the so-called New World" (García Canclini 2005, xxxii). Hybridity is no longer viewed as a strategy for hiding cultural difference and for global homogenization, but to rediscover the values of so-called "endogenous F. Ferretti, 2019 "Decolonising the Northeast: subalterns, non-European heritages and radical geography in Pernambuco", Annals of the American Association of Geographers [early view] https://www.tandfonline.com/doi/full/10.1080/24694452.2018.1554423 
hybridization", thus opposing what Canclini defines "heteronomous hybridization". It is possible to argue that, by highlighting indigenous agency in the nineteenth century revolts, de Andrade pioneered the rescue of indigenous identities currently ongoing in the Northeast.

To introduce de Andrade's works on subaltern groups in the Nordeste, I first analyse the importance of colonial differences and non-European traditions in that region by discussing the historical experience of the revolt of Canudos through the works of de Andrade's inspirations, Euclides da Cunha (1866-1909) and Josué de Castro. In the second part, I discuss de Andrade's conceptualisation of the Northeast as a region marked by colonial oppression and subaltern agency, by analysing two of his major works, A Terra e o Homem no Nordeste and A Guerra dos Cabanos. In the third part, I analyse de Andrade's histories and geographies of Brazilian quilombos (communities of freed slaves) and of the abolitionist movements, highlighting their openings for current scholarship on Afro-Brazilian social movements.

\section{The Northeast of Brazil, and alternative geographical traditions}

In the twentieth century, the state of Pernambuco was the cradle of important critical geographical studies analysed by de Andrade, who recognised his friend Josué de Castro as the

main inspiration in this movement (Andrade 2007). For de Andrade, this was not only a scholarly matter but a political one as he mobilised a prestigious comparison between de Castro and Elisée Reclus, arguing that de Castro was "a fighting geographer, one who played in Brazil a similar role to Reclus's in France" (Andrade 2006, 88). For de Andrade, de Castro's legacy resided mainly in his claims "for the necessity of an agrarian reform which does not start from above, as a gift from dominant classes, but as a conquest from dominated classes, based on popular struggles" (Andrade 2003, 81).

F. Ferretti, 2019 "Decolonising the Northeast: subalterns, non-European heritages and radical geography in Pernambuco", Annals of the American Association of Geographers [early view] https://www.tandfonline.com/doi/full/10.1080/24694452.2018.1554423 
One of de Castro's most famous books, Geografia da Fome published in $1946^{1}$ provided a presentation of North-eastern subaltern histories and geographies, drawing first upon the works of journalist Euclides da Cunha, one of the most famous Brazilian writers and something like a Funding Father of the Brazilian Republic, established in 1889 and very precarious in its first years (Pereira Carris Cardoso 2016). Da Cunha's masterpiece Os Sertões (Cunha, 1902) allowed Brazilian publics to know for the first time the region called Sertão, or Backlands, which was characterised by dramatic droughts and by the domination of latifundia and slavery. With the start of the Republican period, the Backlands were viewed with a sense of otherness and as settled by populations subject to social, racial and moral blame (Campos Johnson 2005). Cunha revealed this world to cultivate Brazilian publics following his experience as a correspondent during the tragic War of Canudos (1896-97). Da Cunha's book is viewed by Luciana Murari as a step towards the geographical invention of Brazil though in a very ironic way, as da Cunha's definition of "geographical fiction" referred to attempts of the official press to make foreign diplomats believe that Brazil had territorial integrity while in fact enormous areas of the hinterland remained out of governmental control. Thus, what da Cunha deemed "fiction as trick" (Murari 2007, 25) is today viewed as a political and discursive device that facilitated Brazil's national construction.

The cause of that war was the revolt led by millenarist leader Antonio Conselheiro, which seriously concerned the central government in Rio. Approximately 25,000 poor peasants and

\footnotetext{
${ }^{1}$ This has not to be confused with the English edition Geography of Hunger, a book which corresponded indeed to later de Castro's 1951 work Geopolítica da Fome. In this paper, all quotes from texts in Portuguese or Spanish have been translated by the author.

F. Ferretti, 2019 "Decolonising the Northeast: subalterns, non-European heritages and radical geography in Pernambuco", Annals of the American Association of Geographers [early view] https://www.tandfonline.com/doi/full/10.1080/24694452.2018.1554423
} 
labourers and mostly of Afro-Brazilian origin or "mixed-blood”, Conselheiro's followers had defeated the first military expeditions sent against them and had taken control of the town of Canudos located between Bahia and Pernambuco. Da Cunha arrived in the region with all racialist prejudices of the European-trained and positivist Brazilian intellectual elite of the day in supporting the "unavoidable" march of civilisation towards crushing barbarous and anachronistic rebels "condemned to civilisation" (Campos Johnson 2005). Many former slaves were not supportive of Republican institutions, and venerated princess Isabel who had signed the abolition act in 1888, as their economic situation had not improved under the Republic. Furthermore, a progressive shift from a plantation economy to cattle-based latifundia systems provoked unemployment in combination with ecological and social unbalances (Andrade 1963).

These revolts, traditionally considered "primitive" by liberal and Marxist historiographies, were reassessed by subaltern scholarship highlighting the distortions provoked by Eurocentric analytical lenses in undermining the revolts of peasants in India (Guha, Chatterjee and Pandey 2010), Southeast Asia (Scott 1985) and of course Brazil (Hecht 2013). As I explain below, de Andrade was a pioneer in this reassessment of peasants', Blacks' and caboclos' revolts in Brazilian scholarship. According to Susanna Hecht, da Cunha's itinerary is striking in that after witnessing the dreadful destruction of Canudos and the massacre of its inhabitants, the writer denounced these crimes, stating that the Brazilian military expedition was "a crime in all the senses of the term, one which deserves denunciation" (Cunha 1902, VI-VII). Da Cunha admired Canudos' ferocious resistance against a modern army and the historical resistance of Black and indigenous communities against battalions of the Bandeirantes, Brazilian colonists from the coast whose expeditions into the hinterland for gold and silver or to settle on

F. Ferretti, 2019 "Decolonising the Northeast: subalterns, non-European heritages and radical geography in Pernambuco", Annals of the American Association of Geographers [early view] https://www.tandfonline.com/doi/full/10.1080/24694452.2018.1554423 
productive land were accompanied by dreadful violence towards local dwellers, sometimes in collaboration with other natives (Hecht 2013, 22).

Da Cunha's narration is suspended between modernistic blame and spontaneous admiration towards the mixed caboclo and $c a f u z^{2}$ populations who lived in the hinterland and that he finally defined as "the bedrock" (Cunha 1902, 594) of the Brazilian nation, inaugurating the ambiguity of Brazilian national myths in attempting to reach a synthesis between primitivism and modernism (Stepan 2000). Da Cunha considered the mixed-blood sertanejo population as the best to settle in the Amazonian region, which was deemed unhealthy for the "Whites". According to Hecht, this was the earliest recognition of indigenous and Afro-descendant identities as a founding part of Brazil. Hecht also compared Canudos with the stories of the Brazilian quilombos, maroons' communities originally composed of Black slaves fleeing into the hinterland, using definitions like "A Quilombo called Canudos" (Hecht 2013, 62), a position that matches both de Andrade's views and Ribeiro's definition of quilombos as “protoBrazilian formations" (Ribeiro, 2000, 153). Additionally, if one considers the material history of settlement beyond histories of "heroic" discovery and exploration, "quilombos can be usefully understood as the main form of colonisation of Brazil's interior" (Hecht 2013, 36). Though Canudos is not generally identified with a quilombo in Brazilian scholarship, it is possible to consider that there are similarities between these historical experiences of subaltern resistance and agency as I explain below.

\footnotetext{
${ }^{2}$ Two of the numerous definitions used in Brazil to describe the different "mixture" degrees of people having some miscegenation between Europeans, Blacks or Indigenous in their descent.

F. Ferretti, 2019 "Decolonising the Northeast: subalterns, non-European heritages and radical geography in Pernambuco", Annals of the American Association of Geographers [early view] https://www.tandfonline.com/doi/full/10.1080/24694452.2018.1554423
} 
De Castro paid tribute to da Cunha by defining him as a "geographer and poet" (Castro 1946, 172) whose work is mobilised to understand the history of the Northeast while considering its geographies and material conditions. This was associated with the dramatic reality of Sertão droughts. According to both authors, thirst and periodical hunger became characteristic features of sertanejo life ad culture and a source of identity. This was the case for Conselheiro, who exhibited his puritan habits to be recognised as a leader by poor peasants. A telling anecdote concerns a priest from another region who "during a sermon, argued that it was possible to fast without suffering hunger by eating some meat for dinner and a cup of coffee in the morning. A [Conselheiro follower] replied: 'but this is not fasting, this is satisfying your appetite"' (Castro 1946, 244-245). While food, water and material life served as an important entry point for de Castro to link his region with the global problems of his day, as also witnessed by de Andrade in the documentary film Josué de Castro cidadão do mundo (Tendler 1994), cultures and identities of subaltern social groups were likewise considered in explaining their revolts and claims.

Another impressive work by de Castro which can be considered as an inspiration for de Andrade was Sete palmos de terra e um caixão [Seven feet of land and a coffin]. In his book, de Castro provided an anecdote of the first North-eastern peasants' unions, whose claim was "to secure for the peasants the right to six feet of earth in which they might rest ... and the privilege of being buried in wooden coffins of their own" (Castro 1969, 7-8). De Castro explained the significance of this claim by arguing that, in a region where most of the population suffers desperate conditions of life, "it is death, not life, that really counts" (Castro 1969, 8). In a situation where "the legacy of slavery remains in force ... the folk singers at fairs have always extolled the indomitable courage of people's leaders who have given their lives

F. Ferretti, 2019 "Decolonising the Northeast: subalterns, non-European heritages and radical geography in Pernambuco", Annals of the American Association of Geographers [early view] https://www.tandfonline.com/doi/full/10.1080/24694452.2018.1554423 
for justice" (Castro 1969, 9), for instance by defending the quilombo of Palmares led by legendary slave Zumbi (Nelson Anderson 1996). According to de Castro, no peasant feared death, which was considered a liberation: as normal burying ceremonies occurred with borrowed coffins that served only before the corpse's deposition in the graveyard and were then reused, "this travesty of ceremony was the supreme humiliation [and] the first League was created to escape this shaming" (Castro 1969, 12). De Castro even identified elements of continuity in the subaltern agency and the peasants' struggles in the Northeast from Palmares and all the episodes of "resistance of insubordinate indigenous and Black maroons of the quilombos, but also of the poor White and Mestizo colons without land" (Castro 1969, 126).

For de Castro, "characteristic of such areas ... is the cruel geography of hunger" (Castro 1969, 25), as well as stories of the resistance of subalterns against landlords' oppression. The stories of the Cangaceiros (Bandits), whom de Castro compared with the figure of Robin Hood (Castro 1969, 62), and revolts such as those of Canudos were considered not as episodes but as the result of "Brazil's colonial history .... desperate attempts to escape the misery of the Northeast" (Castro 1969, 113). De Castro's interest in global hunger was rooted in his experiences with the Northeast and with its histories of Indigenous, Black and subaltern resistance. Being himself "a caboclo, of mixed indigenous Brazilian and European ancestry" (Ziegler 2013, 73) de Castro was proud of being born "on a street which had the illustrious name of Joaquim Nabuco, the great abolitionist" (Mançano-Fernandes and Porto-Gonçalves 2007, 145) and located another of his major works, Men and Crabs, in the mocambos (informal Black and caboclo settlements) around Recife, claiming an activist geography dialoguing with daily struggles of the excluded by capitalism and racism (Ferretti 2019).

F. Ferretti, 2019 "Decolonising the Northeast: subalterns, non-European heritages and radical geography in Pernambuco", Annals of the American Association of Geographers [early view] https://www.tandfonline.com/doi/full/10.1080/24694452.2018.1554423 
As I explain in the following sections, this inspired de Andrade's interest in the history of popular rebellions and insubordination in his region, phenomena which characterised its landscape and its identities. These struggles, often spontaneous and non-ideological, where despised for a long time by Brazilian and international historiography: as I explain in the next section, they are a marker of the Northeast's identity in de Andrade's works, which can be considered as a contribution to the concept of subaltern space.

\section{Subaltern geographies and histories from the Northeast}

Manuel Correia de Andrade was born in 1922 in Vicência, in the Pernambucan Sertão, in a local engenho, a farm for the exploitation of sugarcane. Albeit coming from a well-heeled White family, de Andrade had to endure the hardship of political repression as an activist, and was imprisoned twice for having protested against the two major authoritarian regimes which ruled Brazil during the twentieth century: in 1944 against Getúlio Vargas's Estado Novo, and in 1964 against the military dictatorship (Ferretti 2018). Once delivered, de Andrade lived for one year in France and then returned to Recife, becoming the Chair of Geography for the Federal University of Pernambuco. De Andrade was the protagonist of intense networking with international scholars who visited the Northeast in the 1960s and 1970s, transforming Recife into an international hub for critical development studies (Ferretti 2018).

Politically, de Andrade was admittedly an "undisciplined person", extraneous to what he called “orthodox Marxism": “In Marxism, I can see two lines: one that simply repeats Marx's theories, and a heterodox one" (Andrade 2008, 189). Broadly defining himself as a socialist, de Andrade had resigned from the Communist Party in his youth, claiming that: "They did not allow me reading Trotsky. [Likewise] I left the Catholic Church because they did not allow me

F. Ferretti, 2019 "Decolonising the Northeast: subalterns, non-European heritages and radical geography in Pernambuco", Annals of the American Association of Geographers [early view] https://www.tandfonline.com/doi/full/10.1080/24694452.2018.1554423 
reading Renan” (Lins Rodriguez 2007, 21). Recent work on his archive shows that de Andrade was a close friend and collaborator of Milton Santos, being one of his Brazilian correspondents during the years of Santos's exile (Ferretti 2018) and after $^{3}$ despite their different political views. Indeed, Santos claimed to be a Marxist, even though he likewise refused to belong to a political party (Buss et al., 1991), and all sources indicate that the two men had a solidary relationship all along their careers. Therefore, it is possible to consider that Brazilian critical geography was an umbrella gathering different thinkers who challenged conservative tendencies in the discipline, during the dictatorship and afterwards.

De Andrade can be considered as a protagonist, with Santos, Ruy Moreira, Antonio Carlos Robert Moraes and others, of the critical turn which characterised Brazilian geography after the 1978 Fortaleza Congress of the Association of Brazilian Geographers (Maia 2009). In Pernambuco, de Andrade became a local celebrity as holder of the prestigious Gilberto Freyre Chair and research director in the Joaquim Nabuco Foundation (Lins Rodriguez 2007). Brazilian scholarship discusses his integration in the wider circuits of those radical intellectuals who are considered to be the founders of contemporary Brazilian social sciences, such as Caio Prado Junior and Florestan Fernandes (Andrade 2008). Caio Prado was a member of the Brazilian Communist Party, and his correspondence with de Andrade exposes this latter's originality in matter of agrarian reform. While Caio Prado supported the introduction of smallscale property in the countryside, de Andrade was in favour of the introduction of a system of

\footnotetext{
${ }^{3}$ São Paulo, Instituto de Estudos Brasileiros (hereafter IEB) Acervo Milton Santos, MS-RS-80-029, [Correia de Andrade] to Santos, 5 April 1980.

F. Ferretti, 2019 "Decolonising the Northeast: subalterns, non-European heritages and radical geography in Pernambuco", Annals of the American Association of Geographers [early view] https://www.tandfonline.com/doi/full/10.1080/24694452.2018.1554423
} 
cooperatives. ${ }^{4} \mathrm{He}$ confirmed this by backing the first Pernambucan peasants' leagues in the 1950s and 1960s, together with de Castro, while the Communist Party, "very tied to the official postulates of Marxism-Leninism" (Andrade 1986, 29), did not believe in peasants as a "class". De Andrade's struggles for agrarian reform, social inclusion and democratisation after the military dictatorship are the main insights of his contemporary reception. His works have been saluted as an inspiration by leaders of the MST (Araújo 2002, 152-153), albeit Brazilian scholarship is far from acknowledging him only for agrarian geography (Viotto 2017).

The most famous of de Andrade's books, A Terra e o Homem e no Nordeste, was at the same time a piece inspired by the French tradition of regional geography and a militant work supporting peasants' unions and denouncing "inhuman" conditions of life in the countryside. De Andrade also criticised the "arbitrary" (Andrade 1963, 4) definition of Brazilian Northeast given by the National Council of Geography. This definition considers Nordeste as the region including the states of Alagoas, Bahia, Ceará, Maranhão, Paraíba, Piauí, Pernambuco, Rio Grande do Norte and Sergipe, which are traditionally viewed as the poorest and less "developed" regions of Brazil. Claiming the freedom of geographers in making their regionalisation following different criteria than the state and administrative ones, de Andrade questioned the inclusion of the entire state of Bahia, proposing to include in the Nordeste only its northern part. Most importantly, de Andrade's regionalisation was based on his idea of region as a historical and ecologic complex first defined by ecosystems like the Sertão, identified as a "polygon of droughts" (Andrade 1963, 5). Beyond the Sertão and the lowest and driest landscapes of the Caatinga (savannah), other regions analysed by De Andrade were the

\footnotetext{
${ }^{4}$ IEB, Acervo Caio Prado Junior, CPJ-CP-AND001, de Andrade to Prado, 24 February 1945.

F. Ferretti, 2019 "Decolonising the Northeast: subalterns, non-European heritages and radical geography in Pernambuco", Annals of the American Association of Geographers [early view] https://www.tandfonline.com/doi/full/10.1080/24694452.2018.1554423
} 
coastal Zona de Mata, which is rainier and occupied by major cities, and the Agreste, a "region of transition between Mata and Sertão" (Andrade 1963,14) where agriculture was traditionally more important than livestock breeding.

This book was the only major work of de Andrade to be translated into English. De Andrade's archives in course of inventory at the IEB (Instituto de Estudos Brasileiros) reveal that this was the occasion for opening collaborations with North American scholars including Ronald Chilcote, a specialist in Latin America based at the University of California, Riverside. Writing in Portuguese to de Andrade, Chilcote first expressed interest in de Andrade's work on "The Cabanos war and Black revolts in Pernambuco" and in general in "Brazil and Lusophone Africa" in the context of the Latin American Research Programme and Latin American and Africa Studies Centre of his institution, where de Andrade was invited. ${ }^{5}$ Chilcote likewise travelled to Recife ${ }^{6}$ and was key in providing de Andrade with the contacts for publishing $A$ Terra e o Homem in English, with a translation by geographer Dennis Johnson. ${ }^{7}$ Man and Land appeared accompanied by a preface by Johnson stressing the importance of "the theme of man-land-labour" (Johnson 1980, vii). For Johnson, the interest of the book was not only scholarly, given the urgency of deep social reforms in Brazil, which meant endorsing the role of non-neutral and engaged scholarship, claimed by de Andrade. Johnson's foreword accounts for the close collaboration between the author and the translator, "two professional geographers with a shared interest in Northeast Brazil" (Johnson 1980, vii) and for the updates that it

\footnotetext{
${ }_{5}^{5}$ IEB, Acervo Manuel Correia de Andrade (hereafter MCA), Caixa 36, Chilcote to de Andrade, 20 August 1967. The localization of letters from de Andrade's collection corresponds to the provisional folders that the author consulted in May 2017: the inventory of these materials is ongoing and the numeration of some boxes might have changed.

6 IEB-MCA, Caixa 34, Chilcote to de Andrade, 21 June 1969.

${ }^{7}$ IEB-MCA, Caixa 40, Johnson to de Andrade, 6 December 1976.
}

F. Ferretti, 2019 "Decolonising the Northeast: subalterns, non-European heritages and radical geography in Pernambuco", Annals of the American Association of Geographers [early view] https://www.tandfonline.com/doi/full/10.1080/24694452.2018.1554423 
contained in relation to the previous editions in Portuguese, especially a new chapter on the states of Maranhão and Piauí, and major revisions in the concluding chapter. For this reason, I will quote this book from the 1963 edition in Portuguese for the chapters where there are no updating issues to remain as close as possible to the original de Andrade's thinking, and will use the North-American edition for the remainder.

In his book, de Andrade denounced the dramatic situation experienced by the poor of his region, who often needed to emigrate filling racialised settlements like "barracos, mocambos and favelas" (Andrade 1963, 41) in the largest Brazilian cities. The geographer addressed the colonial history of the region, matching de Castro's views on the persistence of latifundia, which were protected by the state "despite the poor" (Andrade 1963, 43). A key feature of these structures was the system of the engenhos (sugar mills), through which sugarcane was collected and for which, from the sixteenth century, a large number of Black slaves was needed, being the Indians not enough numerous and especially unwilling to do plantation work. The Indians' traditional flees into the hinterland to escape forced plantation work were cited as an example of subaltern agency, like the quilombos established by unruly African slaves. De Andrade aimed to dissipate common views of Africans and indigenous as allegedly bearing all mistreatment with patience by arguing that "the slave was always ready to flee into the forest, to organise quilombos, or even to commit suicide, in short to resist in any way the arrogance of his masters" (Andrade 1963, 74). Yet this did not impede the establishment of a colonial plantation system based on of the trinomial of "latifundium, monoculture and slavery" (Andrade 1963, 61), with dramatic results lasting into de Andrade's days.

F. Ferretti, 2019 "Decolonising the Northeast: subalterns, non-European heritages and radical geography in Pernambuco", Annals of the American Association of Geographers [early view] https://www.tandfonline.com/doi/full/10.1080/24694452.2018.1554423 
Another characteristic of this book is that every chapter, dedicated to a different North-eastern region, is opened by an historical discussion on the colonial history of the region and its longlasting effects. Analysing the state of Alagoas, where the famous quilombo of Palmares was located and exerted a huge influence on the entire region "during the second half of the seventeenth century" (Andrade 1980, 113), de Andrade got rid of Eurocentric views on the colonisation of "empty spaces" exposing how this region had to be conquered by making war against rebel indigenous and at the cost of bloody colonial crimes. Finally, "livestock raisers took the Indians' land and enslaved them by pretext of 'just war"” (Andrade 1980, 133) while remaining Indians had to withdraw into the mountains. In de Andrade's analyses on the Northeast, what stroke was the numeric importance of slaves, reaching up to 200 individuals for the biggest sugar mills in the seventeenth century. According to Jesuit traveller João Antonil, "in Brazil, everything would be impossible" (Andrade 1963, 81) without African slaves, who, living in conditions which de Andrade deemed inhuman, "were for three centuries the pillar of North-eastern sugar industry" (Andrade 1965, 830).

The new chapters added in the English edition analyse the two regions of Maranhão and Piauí, which de Andrade considered as an intermediate area between Northeast and Amazonia. For the colonisation of those regions, the author again identified battles between Indians and colonisers as the condition of European penetration, accompanied by "tremendous disagreements between the colonisers and the Jesuits" (Andrade 1980, 179). As de Andrade ironically argued, while the former simply wanted to kill them, the latter "wanted to catechize the Indians and gather them into villages, but they tenaciously opposed their enslavement" (Andrade 1980, 179). Again, the subaltern was not a passive subject suffering exploitation and massacres, and reacted deploying several forms of agency, from escape to armed resistance.

F. Ferretti, 2019 "Decolonising the Northeast: subalterns, non-European heritages and radical geography in Pernambuco", Annals of the American Association of Geographers [early view] https://www.tandfonline.com/doi/full/10.1080/24694452.2018.1554423 
After the introduction of cotton, a great number of African slaves were deported to Maranhão and started their own secular history of resistance in the region. "The slaves revolted any times resisting their captivity or escaping to the forest ... they called their communities quilombos. They were so numerous that during the Balaiada revolt, one of the most influential leader was a Black named Cosme, chief of a quilombo" (Andrade 1980, 184).

In the Backlands, "the advancement of the populator movement was done by breeders, often slaves, and by small peasants" (Andrade 1965, 174). Here, de Andrade's positions support Hecht's claims that the essential vectors for the "colonisation" of Brazilian hinterlands were not the state or the elite, but poor and racialised communities. Some echoes of da Cunha's works can be found in de Andrade's remarks on the advancing of "civilisation" through the backlands as something performed by "poor cowboys" (Andrade 1963, 174) and not by European elites, albeit at the price of the "death and devastation" (Andrade 1963, 176) of the Indians. Yet, indigenous communities were not few people fleeing before the invaders, but "various groups which dominated the caatingas in the Sertão" (Andrade 1963:176) and had to be expelled or enslaved after long wars.

De Andrade's social denunciations ranged from the "little human" (Andrade 1963, 68) conditions of the engenho to the "inadequate alimentary regime" (Andrade 1963, 89), matching de Castro's statements on the nutritional deficiencies of traditionally used farinha, a less nutritious flour extracted from different plants and mainly from manioc. The persistence of slavery relations was described by defining nineteenth century abolition as the "freedom to change masters" (Andrade 1963, 69) and the twentieth century introduction of agro-industrial methods as a drive towards increasing proletarisation. Matching again de Castro's views, de

F. Ferretti, 2019 "Decolonising the Northeast: subalterns, non-European heritages and radical geography in Pernambuco", Annals of the American Association of Geographers [early view] https://www.tandfonline.com/doi/full/10.1080/24694452.2018.1554423 
Andrade called for support to small peasantry, especially for "a policy of assistance to the small producer" (Andrade 1980, 1989) in opposition to big corporations, a debate which is still ongoing in critical geographical studies on development and food crises (Nally 2016; Ferretti 2019).

At that time, the most urgent conflicts were the class struggles performed by peasants' leagues in the 1960s, which organised roughly 80,000 agrarian workers in the region to claim agrarian reforms against the "subhuman conditions of life" (Andrade 1963, 241) that workers still experienced. Concurrently, de Andrade released a critique of institutional attempts to reform the North-eastern economy, which was not "adapted to the environment and [lacked] systematic study" (Andrade 1963, 222). The geographer appreciated the creation of the SUDENE, (Superintendência do Desenvolvimento do Nordeste), a developmental agency founded in 1959 to foster the social economy in the Northeast and which was then marginalized under the pretext of corruption but due to the critical ideas of its members and inspirers, including de Castro and de Andrade. Nevertheless, de Andrade argued that "more radical measures" (Andrade 1963, 233) were needed, and criticised the SUDENE for becoming an essentially clientelist agency during the years of the military dictatorship (Andrade 2000). For de Andrade, the problem was expressed by the radical alternative "human dignity or revolution" to overcome "the old structures created by the Portuguese" (Andrade 1963, 254), i.e., coloniality of power.

De Andrade's views on development matched de Castro's and Milton Santos's arguments on the need to consider local particularities, criticising the "rather generalized habit of studying foreign experiences and of trying to import them" (Andrade 1973, 112). De Andrade likewise

F. Ferretti, 2019 "Decolonising the Northeast: subalterns, non-European heritages and radical geography in Pernambuco", Annals of the American Association of Geographers [early view] https://www.tandfonline.com/doi/full/10.1080/24694452.2018.1554423 
strove for the South to "theorise back" (Slater 1993) on matters of development, stating a need to study specificities of the Northeast defined as a "problem region" (Região-problema) challenging Brazilian governmental rhetoric of national economic growth. De Andrade also criticised Malthus by denying the alleged overpopulation of the Northeast (namely, the over 20 million inhabitants distributed across 970,000 square kilometres in the 1960s; over 56 million according to the latest Brazilian census). For de Andrade, this population could be sustained with industrial measures by "offering a series of new jobs ... and by modifying the system of land exploitation through the more effective distribution of its property" (Andrade 1973:105). Therefore, this work participated in development studies but also in critiques of development as a neo-colonial and Western-driven approach (Power 2003).

Despite being a "canonised" geographer, de Andrade made one of his most significant contributions as historian of the "Cabanos War", part of the popular revolts that occurred in Northern Brazil during the Regency period (1831-1840) "not only in Pará but also in the northern provinces of Pernambuco (the Cabanada), Maranhão (the Balaiada), and Bahia (the Sabinada and the Muslim slave revolt of 1835) and in the southern region of Brazil (the Farroupilha). Each threatened the future existence of Brazil and in different ways challenged popular exclusion from politics, elite land grabbing, slavery and monarchy" (Harris 2010, 4). According to historian Mark Harris, these terms reflect "the activities of people who live in cabanas in the region's poorest housing structures - palm and wood huts. These inhabitants are called cabanos, a designation carrying associations of backwardness, poverty and sedition" (Harris 2010, 5). The 1830-35 Cabanada analysed by de Andrade in Pernambuco and Alagoas anticipated Canudos and the 1835-40 Cabanagem in Pará, having a strong participation of indigenous communities exhibiting conscious agency and concrete claims (Albuquerque F. Ferretti, 2019 "Decolonising the Northeast: subalterns, non-European heritages and radical geography in Pernambuco", Annals of the American Association of Geographers [early view] https://www.tandfonline.com/doi/full/10.1080/24694452.2018.1554423 
Dantas 2016). These revolts were likewise associated with the presence of quilombos and Black republics that contemporary scholarship confirms were "more common in the North" (Cleary 1998, 118) though targeted by a "war of extermination" (Cleary 1998, 128). In their celebrated account of Brazilian history, Lilia Schwarcz and Heloisa Starling explicitly compare the Cabanagem and the 1804 Haitian revolution. At that time, Brazilian elites "feared Haiti like the Devil himself. Repercussions of the 1804 revolutionary events in Haiti were felt throughout the country" (Schwarcz and Starling 2018, 275).

What is important to consider from de Andrade's works is the case he made for subaltern histories and subaltern spaces, including the use of the term internal colonialism. This represented one of the first attempts made to discuss the early revolts of peasants, indigenous and caboclos which had been "taken superficially" (Andrade 1965, 14) by Brazilian historiography, which had erected until that moment a "silent curtain" on the true "massive revolutions, the popular ones" (Andrade 1965, 200) whose leadership "was supported in large part by Jacuipe Indios and Black slaves" (Andrade 1965, 204). De Andrade noted an early racialisation of the conflict, quoting documents on the "raising of 600 caboclos to fight the federals" (Andrade 1965, 47) and stressing tactics that they had adopted, akin to what are now considered guerrilla tactics. While the geographer acknowledged that this was a "sui generis revolution" (Andrade 1965, 199) supported by Imperial legitimists against the liberals, he considered it as a true expression of the story of North-eastern popular antiauthoritarian rebellions. This was similar to later Shilliam's claims about the Haitian case, observing "a longstanding relationship between enslaved Africans and indigenous Taino peoples" (Shilliam 2017, 275), and anticipated arguments of the MCD movement on internal colonialism as exposed above.

F. Ferretti, 2019 "Decolonising the Northeast: subalterns, non-European heritages and radical geography in Pernambuco", Annals of the American Association of Geographers [early view] https://www.tandfonline.com/doi/full/10.1080/24694452.2018.1554423 
Current Brazilian scholarship notices how de Andrade played a pioneering role in asserting that there was a "political cabano" (Almeida 2010, 12) in opposition to the prejudices of the pre-political and the "primitive rebels" mentioned above, and in "decriminalizing the cabano" (Almeida 2010, 39) by appreciating the social relevance of these rebels' claims. Among his Brazilian contemporary scholars, de Andrade criticised Gilberto Freyre and his "LusoTropicology" (Andrade 2007, 11) for his excessive sympathies toward the "civilisation" of Portuguese conquerors, sympathies which were also strongly criticised by the famous author of the Black Brazilian Genocide, Abdias Nascimento (2016). For de Andrade, direct action and subaltern agency were the marker of North-eastern social histories. In his works on quilombos and abolitionism which I address in the next section, de Andrade enlarged this analysis to the entire Brazil and traced compelling lines of continuity between historical experiences and the most urgent social struggles of his days, not so far by contemporary problems exposed by recent scholarship on Latin American social movements (Stahler-Sholk, Vanden and Becker 2014; Finn and Hanson 2017).

\section{A quilombo's geography}

In 1988, the new Brazilian Constitution, which symbolically put an end to the military dictatorship that had run the country since 1964, granted historical rights to the descendants of ancient quilombo communities: "The definitive property rights of remanescentes ["remnants"] of quilombos that have been occupying the same lands are hereby recognised, and the state shall grant them title to such lands" (1988 Brazilian Constitution, Art. 68). Rich Brazilian and international literature in recent years has discussed the outcomes of this new legislative framework, highlighting its contradictions and the disappointing situation of racism,

F. Ferretti, 2019 "Decolonising the Northeast: subalterns, non-European heritages and radical geography in Pernambuco", Annals of the American Association of Geographers [early view] https://www.tandfonline.com/doi/full/10.1080/24694452.2018.1554423 
marginalisation and discrimination that Afro-Brazilian communities still face. This law often remained unapplied and Afro-Brazilian communities still struggle for full social and spatial inclusion (Kenny 2011). The economic interests engendered by the possibility of owning the land of the ancient quilombos also led to heated debates on what a quilombo effectively was, and on who effectively has the right to be considered as a remnant (Farfán-Santos 2015). This debate is complicated by the great complexity of the historical and geographical forms taken by the quilombola phenomenon, which several authors consider a system of social organisation not limited to one "race" (Leite 2017), and by the interests of ruling classes to hinder access to land property by descendants of Afro-Brazilian communities, who often reside in the favelas (Campos 2005). Moreover, racial categories in Brazil remain a complex issue, considering that the generic definition of pardo, that is an individual of mixed origin, is traditionally associated with ideas of blackness and marginalization, and was recently included in political debates for the establishment of racial quotas (Schwarcz 2013). While the result of this political situation was a great slowness in the effective recognition of the rights guaranteed by the Brazilian constitution and the lasting of complex social exclusions based on matters of wealth, (socially constructed) race or patriarchy, quilombos increasingly are recognised as an unavoidable feature of the history and territorial formation of Brazil. Recently, quilombos were described by Sam Halvorsen as spatial models challenging Western ideas of bounded territory (Halvorsen 2017) and contributed to the elaboration of the theory of "freedom as marronage" by Neil Roberts (2015).

In the geographical tradition, an eminent precedent in the consideration of quilombolas (quilombo residents) as historical and geographical actors was Elisée Reclus's New Universal Geography. In his critique of European (French, Dutch and English) colonialism in the

F. Ferretti, 2019 "Decolonising the Northeast: subalterns, non-European heritages and radical geography in Pernambuco", Annals of the American Association of Geographers [early view] https://www.tandfonline.com/doi/full/10.1080/24694452.2018.1554423 
Guianas, Reclus included an appreciation of the maroons' communities. "Black republics have been constituted in the three littoral Guianas, English, Dutch and French ... These communities live in peace, without rival ambitions or competition for power: equals in wealth, the Blacks of the forest are equals in rights" (Reclus 1894, 48, 52). Regarding Reclus's argument on the liberty of the forest, Brazilian geographical scholarship argues for the existence of ecological links between the quilombo communities settled in the littoral forests of the Northeast, i.e. the ecosystem of the Mata Atlantica, and their environment, whose preservation was possible thanks to the actions of the quilombo people, who were unwilling to destroy the forest (Silva 2008).

In his chapter on the Brazilian Northeast, Reclus praised the most famous Brazilian quilombo: Palmares. "In the early seventeenth century, the slaves rose up and forty of them went living in the forest far from their masters. They established their Quilombo ... one hundred kilometres from Pernambuco ... The main group went farer, where now we find the state of Alagoas ... and transformed the Quilombo of Palmares in a city. The rebels became so strong that they constituted a state negotiating with the Portuguese and Dutch conquerors. The Republic reached 20,000 inhabitants, and the capital 6,000... In no place, in Brazil, fields were better cultivated ... However, this community of free people scared the planters, who organised an army of 7,000 men against the Blacks. Defeated, they came back with cannons and seized the city, bringing men, women and children prisoners in Pernambuco. Many fighters preferred to die instead to fall again in slavery" (Reclus 1894, 228-229). If these idealised views are nuanced by recent scholarship highlighting the complexity of quilombos' histories and their conflicts, what was revolutionary in Reclus's work is the attention of a European scholar taking seriously subaltern groups and their struggles. According to Schwarcz and Starling, while the

F. Ferretti, 2019 "Decolonising the Northeast: subalterns, non-European heritages and radical geography in Pernambuco", Annals of the American Association of Geographers [early view] https://www.tandfonline.com/doi/full/10.1080/24694452.2018.1554423 
Haitian example scared Brazilian planters, the most popular model for Black insubordination in Brazil was an endogenous North-eastern one, that is Palmares, which "became a national symbol of the long tradition of bravery and resistance of Brazil's quilombo warriors" (Schwarcz and Starling 2018, 118).

The importance of considering Reclus's position is demonstrated by the fact that de Andrade edited the first book of Reclus's collected essays translated into Portuguese, with a substantial introduction by the editor, who especially was interested in Reclus's works on colonialism. For de Andrade, Reclus showed "how the coloniser was moved by his interests in exploiting resources and native populations, rather than to bring the faith in Western civilisation to peoples deemed savage and barbarous" (Andrade 1985, 26). Although he equally was influenced by Marxism, de Andrade claimed the legacy of anarchist geographers Reclus and Kropotkin to plead for his idea of an engaged geography, explicitly refusing any pretention for the neutrality of scholars, because at that moment: "Against the geography of power, a geography of the people is today rising" (Andrade 2008, 97).

For the history of quilombos, positions similar to Reclus's were expressed by radical Brazilian historian Clovis Moura, addressing quilombos as spaces of freedom and as a radical challenge to the colonial and capitalist establishment (Moura 2001). If this idea overtook previous prejudices despising the alleged "pre-political" and "primitive" revolts, recent scholarship criticised Moura for some simplification of opposition between quilombos and the world outside quilombos and argued for empirically grounded studies that thoroughly explore "the highly complex and contradictory social and economic networks that bound quilombolas, slaves, freed people, and slaveholders together" (Miki 2012, 499). Drawing upon works by F. Ferretti, 2019 "Decolonising the Northeast: subalterns, non-European heritages and radical geography in Pernambuco", Annals of the American Association of Geographers [early view] https://www.tandfonline.com/doi/full/10.1080/24694452.2018.1554423 
Flávio dos Santos Gomes considering the "Black field" (Gomes 1996, 278) as a complex intersection of social networks, Yuko Miki especially focuses on the nineteenth century, when an increasing number of quilombos were established in the proximity of cities and plantations rather than in faraway savannas and forests, engendering complex territorial relations. However, all these authors generally converge in appreciating the primary importance of quilombos for the social and territorial formation of Brazil.

In the context of the celebrations for the tricentenary of Palmares in 2001, Moura edited a collective book, which had a contribution from de Andrade with a chapter on the "quilombo's geography". De Andrade was among the first who claimed the political nature of quilombos and expressed a need for their urgent study, considering that "slavery still occurs, in diverse forms, in several places in the world, including Brazil" (Andrade 2001, 77). Focusing on the autonomous agency of quilombo people, de Andrade evoked their "fighting geography", a definition that was resumed by Miki under the label of "insurgent geography". For de Andrade, the importance of quilombola spaces lay in the formation of a nonstatist idea of territory and in their exceptional spread all over Brazil, even though the author noticed the impossibility of a "rigorous geography of quilombo", given the great complexity and variety of the spatial forms that this phenomenon took during its plurisecular history. Quilombos had different characteristics "in different places and at different times" (Andrade 2001, 79), ranging from ephemeral settlements to large and well-organised federations of quilombos and mocambos. Quilombos were characterised by "cultural differentiations" (Andrade 2001, 82), often due to the diverse origins of their components, of whether they were born in Brazil or came from different regions of Africa.

F. Ferretti, 2019 "Decolonising the Northeast: subalterns, non-European heritages and radical geography in Pernambuco", Annals of the American Association of Geographers [early view] https://www.tandfonline.com/doi/full/10.1080/24694452.2018.1554423 
What was clear to de Andrade is that quilombos were inserted in networks of colonial relations still lasting after Brazil's formal independence from Portugal in 1822, first due to the "lack of the invaders' knowledge of territory" (Andrade 2001, 79). For de Andrade, a very important point was "the frequent alliance between Blacks and Indigenous when whole tribes were persecuted and often annihilated by the Bandeirantes" (Andrade 2001, 80). While this early "convergence of Blacks and Indians against the colonisers" (Andrade 2001, 80) can be considered only as a part of a situation characterised by in-betweenness and complex negotiations and agencies (Miki 2012), the importance of these Brazilian visions was in establishing the bases for alternative political agendas based on non-European traditions, claimed by MCD authors and by studies on hybridity.

From the standpoint of economy, de Andrade matched the positions of SUDENE economist Celso Furtado (likewise an opponent to the military dictatorship), who questioned common beliefs that Spanish and Portuguese colonisers brought feudalism to South America without developing capitalistic production structures. For de Andrade, the Brazilian "sugarcane plantation" (Andrade 2001, 81) indeed was a capitalistic enterprise, one inserted in the wider context of colonial modernity; therefore, the class struggle of indigenous, Blacks and caboclos against slavery and exploitation had no less dignity than the later struggles of European and North American proletariats.

De Andrade's idea of quilombo remained a relational one, based on the notion that "it was not a close society" (Andrade 2001, 83), as quilombos were in frequent trade relations with their neighbours (indigenous, planters, Blacks still in slavery, etc.) and in the case of the strongest federations such as Palmares, they directly could negotiate conditions with the colonial F. Ferretti, 2019 "Decolonising the Northeast: subalterns, non-European heritages and radical geography in Pernambuco", Annals of the American Association of Geographers [early view] https://www.tandfonline.com/doi/full/10.1080/24694452.2018.1554423 
authorities. Going beyond common beliefs regarding the simple commiseration of the victims of state repression, de Andrade focused on the military and geostrategic strengths of quilombos' resistance, which first were the possibility of fleeing further and further in the interior, but then also the possibility of using a better knowledge of the terrain to develop guerrilla tactics, a situation that anticipated later myths of the "militant tropicality" analysed by Clayton (2013). Finally, de Andrade connected the history of the quilombos with all the histories of revolts addressed above, by observing that, in the Cabanos war in Pernambuco and Alagoas, "rebels were predominantly Black, mulattos and $\operatorname{cabras}^{8} \ldots$ to whom Whites of the poorest social classes united" (Andrade 2001, 84). Therefore, a sort of unity of the "excluded" occurred in these wide social mobilisations, radicalising experiences such as the Cabanos war that "had begun as a political confrontation between oligarchic groups in 1831" (Andrade 2001, 86).

In this vein, de Andrade considered that the formal abolition of slavery did not stop the formation of quilombos because it did not resolve the deepest social problems, including internal colonialism and coloniality of power. In a book tracing a connection between the 1888 abolition of slavery and the twentieth century struggles for agrarian reform, de Andrade argued that these needs "arose both as a consequence of the conquest of Brazilian territory by the Portuguese, of the system of land use and occupation which was imposed to the indigenous population living in this large territory, and the big contingents of slaves brought from Africa" (Andrade 1991, 5). Anticipating MCD readings on the lasting of colonial structures through the process of formal decolonisation of Latin American countries (Mignolo 2005), de Andrade

\footnotetext{
${ }^{8}$ Another racial classification of that time, between the "pure" Black and the mulatto.

F. Ferretti, 2019 "Decolonising the Northeast: subalterns, non-European heritages and radical geography in Pernambuco", Annals of the American Association of Geographers [early view] https://www.tandfonline.com/doi/full/10.1080/24694452.2018.1554423
} 
noted that African slaves did not play a major role in the fights for Brazil's independence from Portugal, because the elites of European descent who took the lead of that movement were not interested in questioning the institution of slavery, including their most radical components. "Despite their republicanism, even the Pernambuco revolutionaries of 1817-1824 did not take any effective measure for abolition" (Andrade 1991, 14-15). Therefore, abolition was seen by de Andrade as a social, colonial and postcolonial issue rather than juridical and political.

One of de Andrade's main arguments was that the 1888 abolition did not come from the sensitivity of Emperor Dom Pedro II and his daughter Isabel, inspired by their acquaintance with European liberals opposed to slavery, but that it occurred as an outcome of centuries of revolts and subaltern resistance, albeit Brazilian narratives recall the role played by international pressures, especially from Great Britain. "We should demystify the idea that abolition started from a movement of idealistic and uninterested Whites. [It started] from a movement of slaves who, aware of the unjust situation they suffered, revolted, killed the lords, or simply fled in the quilombos ... Many leaders of the ruling classes started to fear a generalised slaves' uprising and understood that it was more sensible to concede the abolition by legal and peaceful ways rather than to face an armed struggle" (Andrade 1991, 33-34). As in Haiti, principles of equality and freedom stated by the 1789 declaration of rights were not applied by benevolent Europeans, and freedom was taken directly by the interested people (Buck-Morss 2009) after centuries of active and passive resistance.

However, the principal issue with abolition (and with the consequential transformation of Brazil from an empire to a federal republic in 1889), was the denial of land to the freed slaves, in accordance with the 1850 Land Law, which regulated the private property of land, thus

F. Ferretti, 2019 "Decolonising the Northeast: subalterns, non-European heritages and radical geography in Pernambuco", Annals of the American Association of Geographers [early view] https://www.tandfonline.com/doi/full/10.1080/24694452.2018.1554423 
impeding "the access of poor immigrants and citizens to small-scale property" (Holston 2008, 133). De Andrade identified two further moments for this denial in Brazilian history: 1889, when the new republican government refused to give the land surrounding navigable rivers and the newly constructed railways for agricultural development, and 1964, when the military dictatorship definitively rejected a similar proposal, part of an agrarian reform plan proposed "by president João Goulart" (Andrade 1991, 37). This confirmed Ribeiro's argument that Brazil's progression from colony to empire and later republic, never really mattered to "the power of the plantation bosses" (Ribeiro, 2000, 152). For de Andrade, the main lesson that Brazilian social movements must take from the abolitionist experience of a century before was the effectiveness of radical direct action, considering that its greatest accomplishment was that slaves were freed without a reason for the masters to claim a refund. This implied "smashing the right to property. This was far more advanced than the laws proposed today for the agrarian reform" (Andrade 1991, 8).

Finally, de Andrade showed how "subalterns" and their non-European traditions were effective for impacting the entire Brazilian history, including territorial formation, by attributing a great deal of the so-called "colonisation" of the hinterland to quilombolas and caboclos. Although this happened in greatly contested and complex contexts and does not leave room for generalisation, analysing subaltern spaces proved to be an effective way to challenge more traditional Brazilian histories, based on dates such as 1822 (independence), 1888 (abolition) and 1889 (republic) appearing more superficial, as most of them neglected the deep problems lasting beyond these formal events in Brazilian society.

\section{Conclusion}

F. Ferretti, 2019 "Decolonising the Northeast: subalterns, non-European heritages and radical geography in Pernambuco", Annals of the American Association of Geographers [early view] https://www.tandfonline.com/doi/full/10.1080/24694452.2018.1554423 
In his work on subaltern spaces, Clayton calls for more studies in subaltern histories and geographies, given that the subaltern "has a complex and global historical geography. It matters that subaltern space looks different from sixteenth-century Spanish America, colonial and postcolonial India, or Gramsci's fascist Italy" (Clayton 2011, 251). The case of North-eastern Brazil and its alternative geographical traditions add some important insights to the notion of subaltern spaces. As I exposed above, geographers such as de Andrade focused on the complexity and intersectional nature of those spaces, showing awareness of the connexions between spatial, racial and social subalternity. De Andrade was an empiricist scholar; therefore, it would be difficult to seek discussions of counter-epistemes in his elaborations as Shilliam did with Voodoo and Rastafari thinking. However, this paper has shown that de Andrade's analyses of the historical revolts in the Northeast and of the abolitionist and quilombola struggles throughout Brazilian histories give an important contribution to Spivak's interrogations on the subaltern's voice: Brazilian subalterns spoke through their acts, exerting a plurisecular agency and influence thorough revolt, community building, and different levels of negotiation that marked the entire Brazilian history. Like the Haitians studied by James, Buck-Morss, Shilliam and others, they took their freedom without asking their European or White counterparts. Like Waman Puma in Mignolo's interpretation, they derived their idea of democracy not from the Enlightenment or other theoretical inspirations, but from their daily communitarian practices and their own traditions. Subalterns spoke through direct action, a feature also addressed in the anarchist tradition, of which de Andrade was aware.

Crucially, de Andrade provides examples on how to engage in critical reflections on subaltern spaces despite the limitations of colonial archives (Legg 2016). He reconstructed subaltern histories of his land by critically investigating and comparing official records, oral histories

F. Ferretti, 2019 "Decolonising the Northeast: subalterns, non-European heritages and radical geography in Pernambuco", Annals of the American Association of Geographers [early view] https://www.tandfonline.com/doi/full/10.1080/24694452.2018.1554423 
and traditions. Naturally, this does not resolve the contradiction in which a subaltern, if speaking, is no longer a subaltern, because de Andrade was an intellectual who addressed these concerns from a historiographic standpoint. However, anticipating notions of hybridity and mistura, de Andrade's works can still valuably contribute to discussions in the fields of subaltern, postcolonial and decolonial studies. His work can potentially offer additional insights, from a Brazilian perspective, into contemporary issues on social and racial inclusion. De Andrade was a political dissident, persecuted and imprisoned for his ideas, and worked in connection with the social movements of his region, connecting colonial history with the social reality of the peasant struggle of his day. Therefore, one can argue that socially engaged scholarship can talk with subalterns, not to "give voice" to them, but to engage with relevant political and social issues. This is relevant for today scholarship and activism denouncing the contradictions between displayed notions of (racial and general) democracy in Brazil and the lasting contradictions of social exclusion. The ongoing political crisis in Brazil is aggravating the processes highlighted by James Holston about the failure of the Brazilian state, even when it was ruled by left-wing Lula and Dilma governments, in securing a standard of life for all its citizens and to prevent land grabbing and extractivism (Holston 2008). For Brazilian universities, of which the PT (Workers Party) was especially proud given the great increase in numbers that they experienced under petista governments, scholars likewise highlight the limitations of these politics. For instance, they criticise Lula's commitment to enhance the FIES (Fundo de Financiamento Estudantil), considered as an instrument to drain public money in favour of the private educational sectors (Pinto 2016). Calls to rediscover "the centrality of more than political citizenship and related civil liberties" in a situation where "political democracy is not enough to secure civil and social citizenship" (Holston 2008, 310) are particularly apposite. Insurgent and subaltern histories matter to this agenda.

F. Ferretti, 2019 "Decolonising the Northeast: subalterns, non-European heritages and radical geography in Pernambuco", Annals of the American Association of Geographers [early view] https://www.tandfonline.com/doi/full/10.1080/24694452.2018.1554423 
It is also possible to argue that de Andrade and authors such as Santos and de Castro, showed an early awareness of concepts such as colonial difference, internal colonialism and coloniality of power, which were discovered only in relatively recent years in "international" (i.e., Englishspeaking) scholarship. Such sensitivity was accordingly connected with their own origins in the Northeast and in their direct experience of racialised and marginalised groups in that region. Thus, I would conclude that, for English-speaking scholarship, conducting more effort in considering different geographical traditions, including those that were written in other languages, definitively can serve the agenda of decolonising academia.

\section{Acknowledgements}

Many thanks to Alun Jones for his rereading and his suggestions. In Brazilian matters, I need to acknowledge all the members of the Network Rede Brasilis and of the USP Laboplan, and especially Breno Viotto Pedrosa, Fábio Betioli Contel and Guilherme Ribeiro, for all the fruitful conversations I had with them. I also especially acknowledge the three anonymous readers for the Annals, and editor Nik Heynen, for their great suggestions and insights.

\section{Funding}

This research was supported by the Royal Irish Academy with a 2017 Charlemont Travel Grant, and by the UCD College of Social Science and Law Research Support Scheme with research grant R17353 “Inventing Critical Development”.

\section{References}

F. Ferretti, 2019 "Decolonising the Northeast: subalterns, non-European heritages and radical geography in Pernambuco", Annals of the American Association of Geographers [early view] https://www.tandfonline.com/doi/full/10.1080/24694452.2018.1554423 
Almeida, L.S. de. 2010. Manuel Correia de Andrade: os empobrecidos e a terra. Economia política do desenvolvimento 3: 9-44.

Albuquerque Dantas, M. 2016. La Guerra de los Cabanos. Participación indígena en la formación del Estado nacional brasileño en el siglo XIX. Revista de Indias 266(76):109-136.

Anderson, K. 2008. "Race" in post-universalist perspective. Cultural Geographies 15: 155171.

Andrade, M.C. 1963. A terra e o homem no Nordeste. São Paulo: Editora Brasiliense.

Andrade, M.C. 1965. A Guerra dos cabanos. Rio de Janeiro: Conquista.

Andrade, M.C. 1973. Paisagens e problemas do Brasil, São Paulo: Editora Brasiliense.

Andrade, M.C. 1980. The Land and People of Northeast Brazil. Albuquerque: University of New Mexico Press.

Andrade, M.C. 1986. Elisée Reclus, geografia [Elisée Reclus, geography]. Sao Paulo, Atica.

Andrade, M.C. 1986. Lutas camponesas no Nordeste. São Paulo: Editora Ática.

Andrade, M.C. 1991. Abolição e reforma agrária. São Paulo: Editora Ática (2 ${ }^{\text {nd }}$ ed.).

Andrade, M.C. 2000. Memória: o homem do Nordeste. Teoria e Debate 45: http://csbh.fpabramo.org.br/o-que-fazemos/editora/teoria-e-debate/edicoes-

anteriores/memoria-o-homem-do-nordeste-entrevista-com-

Andrade, M.C. 2001. Geografia do quilombo. In Os quilombos na dinâmica social do Brasil, ed. C. Moura, 75-86. Maceió: EDUFAL.

Andrade, M.C. 2003. Josué De Castro e o Brasil. São Paulo: Editora Fundação Perseu Abramo. Andrade, M.C. 2006. Geografia ciência da sociedade. Recife: Editora Universitária. Andrade, M.C. 2007. A Geografia no contexto das ciencias sociais em Pernambuco. RBCS 22 (65): 9-15.

F. Ferretti, 2019 "Decolonising the Northeast: subalterns, non-European heritages and radical geography in Pernambuco", Annals of the American Association of Geographers [early view] https://www.tandfonline.com/doi/full/10.1080/24694452.2018.1554423 
Andrade, M.C. 2008. Faces de uma amizade. Manuel Correia de Andrade e Caio Prado Jr. In Heidemann, H.D, Iumatti, P. and Seabra, M. (eds.). Caio Prado Jr. e a Associação dos Geógrafsos Brasileiros. São Paulo: Edusp.

Araújo, R.C.B. 2002. O fio e a trama. Depoimento de Manuel Correia de Andrade. Recife: UFPE.

Bressey, C. 2011. Race/Ethnicity. In The SAGE handbook of geographical knowledge, eds. J. Agnew and D. Livingstone, 418-429. London: SAGE Publications.

Buck-Morss, S. 2009. Hegel, Haiti and universal history. Pittsburgh: University of Pittsburgh Press.

Buss, M.D., Mamigonian, A., Machado V.V. and Pereira M.F.A. 1991. Entrevista com o professor Milton Santos. Geosul 6: 170-201.

Campos, A. 2005. Do quilombo à favela: a produção do espaço criminalizado no Rio de Janeiro. Rio de Janeiro: Bertrand Brasil.

Campos Johnson, A.M. 2005. Subalternizing Canudos. MLN 120 (2): 355-382.

Carter, E. 2018. Population control, public health, and development in mid twentieth century Latin America. Journal of Historical Geography, early view https://www.sciencedirect.com/science/article/pii/S0305748817302128

Castro, J.d. 1946. A geografia da fome. Rio de Janeiro: O Cruzeiro.

Castro, J.d. 1969. Death in the Northeast. New York: Random House.

Clayton, D. 2011. Subaltern space. In The SAGE handbook of geographical knowledge, eds. J. Agnew and D. Livingstone, 246-261. London: SAGE Publications.

Clayton, D. 2013. Militant tropicality: war, revolution and the reconfiguration of 'the tropics' c.1940-c.1975. Transactions of the Institute of British Geographers 38 (1): 180-192.

F. Ferretti, 2019 "Decolonising the Northeast: subalterns, non-European heritages and radical geography in Pernambuco", Annals of the American Association of Geographers [early view] https://www.tandfonline.com/doi/full/10.1080/24694452.2018.1554423 
Cleary, D. 1998. Lost altogether to the civilised world: race and the Cabanagem in Northern Brazil. Comparative Studies in Society and History 40 (1): 109-135.

Davies, Andy, 2017. Exile in the homeland? Anti-colonialism, subaltern geographies and the politics of friendship in early twentieth century Pondicherry. Environment and Planning D, Society and space 35 (3): 457-474.

Davies, Archie, 2018. Milton Santos: The conceptual geographer and the philosophy of technics Progress Human Geography [early view http://journals.sagepub.com/doi/full/10.1177/0309132517753809]

Dussel, E. 2013, Ethics of liberation in the age of globalization and exclusion. Durham and London: Duke University Press.

Escobar, A. 2010. Worlds and knowledges otherwise. In Globalization and the decolonial option eds. W. Mignolo and A. Escobar, 33-64. London: Routledge.

Esson, J., Noxolo, P., Baxter, R., Daley, P, Byron, M. 2017. The 2017 RGS-IBG chair's theme: decolonising geographical knowledges, or reproducing coloniality? Area 49 (3): 384-388.

Farfán-Santos, E. 2015. Fraudulent identities: The politics of defining quilombo descendants in Brazil. The Journal of Latin American and Caribbean Anthropology 20 (1): 110-132.

Featherstone D. 2013. Black internationalism, anti-fascism and the makings of solidarity. Soundings: A Journal of Politics and Culture, 55: 94-107.

Ferretti, F. 2018. Geographies of internationalism: radical development and critical geopolitics from the Northeast of Brazil, Political Geography 63: 10-19.

Ferretti, F. 2019. Subaltern geopolitics from the Northeast of Brazil: hunger and food studies against Malthus Geopolitics [under review].

Ferretti, F. and Viotto, B. 2018. Inventing critical development: a Brazilian geographer and his Northern networks. Transactions of the Institute of the British Geographers 43(4): 703-717.

F. Ferretti, 2019 "Decolonising the Northeast: subalterns, non-European heritages and radical geography in Pernambuco", Annals of the American Association of Geographers [early view] https://www.tandfonline.com/doi/full/10.1080/24694452.2018.1554423 
Finn J.C. and Hanson A.M. 2017. Critical geographies in Latin America. Journal of Latin American Geography 16: 1-15.

García Canclini, N. 1995. Hybrid cultures. Strategies for entering and leaving modernity. Minneapolis: University of Minnesota Press.

Gidwani, V. 2009. Subalternity. In International encyclopaedia of human geography, eds. N. Thrift and R. Kitchin, 65-71. Amsterdam/Boston: Elsevier.

Gilroy, P. 1993. The black Atlantic: Modernity and double consciousness. London: Verso.

Gomes, F.S. 1996. Quilombos do Rio de Janeiro no século XIX. In Reis, J.J. and Gomes F.S. (eds.) Liberdade por um fio: historia dos quilombos no Brasil. Sāo Paulo: Companhia das letras: 263-290.

Grosfoguel, R. 2008. Towards a decolonial transmodern pluriversalism. Tabula Rasa 9: 201215.

Guha, R., Chatterjee, P. and G. Pandey. 2010. Subaltern studies: Writings on South Asian history and society. Oxford: Oxford University Press.

Halvorsen, S. 2018. Decolonising territory: Dialogues with Latin American knowledges and grassroots strategies. Progress in Human Geography, early view, doi: $10.1177 / 0309132518777623$

Harris, M. 2010. Rebellion on the Amazon: the Cabanagem, race, and popular culture in the North of Brazil, 17.98-1840. New York: Cambridge University Press.

Hecht S. B. 2013 The Scramble for the Amazon and the 'Lost Paradise' of Euclides da Cunha. Chicago: The University of Chicago press.

Holston, J. 2008. Insurgent citizenship. Disjunctions of modernity and citizenship in Brazil. Princeton: Princeton University Press.

F. Ferretti, 2019 "Decolonising the Northeast: subalterns, non-European heritages and radical geography in Pernambuco", Annals of the American Association of Geographers [early view] https://www.tandfonline.com/doi/full/10.1080/24694452.2018.1554423 
James C.R.L. 1938. The Black Jacobins, Toussaint L'Ouverture and the San Domingo Revolution. London: Secker \& Warburg.

Jazeel, T. 2014. Subaltern geographies: geographical knowledge and postcolonial strategy. Singapore Journal of Tropical Geography 35 (1): 88-103.

Johnson, D. 1980. Introduction. In Andrade M.C. The land and people of Northeast Brazil. Albuquerque: University of New Mexico Press, vii-viii.

Kenny, M.L. 2011. Making heritage in Brazilian Quilombos. Antipoda 12: 91-111.

Legg, S. 2016. Empirical and analytical subaltern space? Ashrams, brothels and trafficking in colonial Delhi. Cultural Studies 30: 793-815.

Legg, S. 2017. Decolonialism. Transactions of the Institute of British Geographers 42 (3): 345 348.

Leite, I.B. 2015. The Brazilian quilombo: 'race', community and land in space and time. The Journal of Peasant Studies, 42 (6): 1225-1240.

Linebaugh, P., Rediker, M. 2000. The Many-Headed hydra: Sailors, slaves, commoners, and the hidden history of the revolutionary Atlantic. Boston: Beacon Press.

Lins Rodriguez, J. (ed.). 2007. O mestre da Geografia. João Pessoa: Fundação Casa de José Américo.

Maia, D.S. 2009. O pensamento de Manuel Correia de Andrade e a sua obra A terra e o homem no Nordeste. Scripta Nova 13(288): http://www.ub.edu/geocrit/sn/sn-288.htm\#a2

Mançano-Fernandes, B., Porto-Gonçalves C.W. 2007 Josué de Castro, vida e obra. São Paulo: Expressão Popular.

Melgaço L 2017 Thinking outside the bubble of the Global North: introducing Milton Santos and 'the active role of geography'. Antipode 49(4): 946-951.

Melgaço, L. \& Prouse, C. Eds. 2017. Milton Santos: Pioneer in geography. London: Springer.

F. Ferretti, 2019 "Decolonising the Northeast: subalterns, non-European heritages and radical geography in Pernambuco", Annals of the American Association of Geographers [early view] https://www.tandfonline.com/doi/full/10.1080/24694452.2018.1554423 
Mignolo, W. 2005. The idea of Latin America. Oxford: Blackwell.

Mignolo, W. 2010. Introduction. In Globalization and the Decolonial Option eds. W. Mignolo and A. Escobar, 1-21. London: Routledge.

Miki, Y. 2012. Fleeing into slavery: The insurgent geographies of Brazilian Quilombolas (Maroons),1880-1881. The Americas 68 (4): 495-528.

Mosher, J.C. 2008. Political struggle, ideology and state building, Pernambuco and the construction of Brazil, 1817-1850. Lincoln and London: University of Nebraska Press.

Murari, L. 2007. Brasil, ficção geográfica [Brazil, Geographical Fiction]. São Paulo: Annablume.

Nally, D. 2016. Against food security: on forms of care and fields of violence. Global Society 30: 558-582.

Nascimento, A. 2016. O genocídio do negro brasileiro. São Paulo: Retrospectiva.

Nash, C. 2003 Cultural geography: anti-racist geographies. Progress in Human Geography 27: 641-644.

Nelson Anderson, R. 1996. The Quilombo of Palmares: A new overview of a maroon state in seventeenth-century Brazil. Journal of Latin American Studies 28 (3): 545-566.

Oliveira, J.P. de. 2010. ¿Una etnología de los indios misturados? Identidades étnicas y territorialización en el Nordeste de Brasil. Desacatos 33: 13-32.

Pereira Carris Cardoso, L. 2016. Intelectuais, militares, instituições na configuração das fronteiras brasileiras. 1883-1903. São Paulo: Alameda.

Pinto, J.M.R. 2016. Uma análise da destinação dos recursos públicos, direta ou indiretamente, ao setor privado de ensino no Brasil. Educação e Sociedade 37(134): 133-152.

Porto-Gonçalves, C.W. 2005. Apresentação da edição em português. In A colonialidade do saber. Eurocentrismo e ciências sociais ed. E. Lander, 3-5. Buenos Aires: CLACSO.

F. Ferretti, 2019 "Decolonising the Northeast: subalterns, non-European heritages and radical geography in Pernambuco", Annals of the American Association of Geographers [early view] https://www.tandfonline.com/doi/full/10.1080/24694452.2018.1554423 
Porto-Gonçalves, C.W. and Araújo Quental P. 2012. Colonialidade do poder e os desafios da integração regional na América Latina. Polis 31 http://polis.revues.org/3749

Power, M. 2003. Rethinking development geographies. London: Routledge.

Quijano, A. 2010. In Globalization and the decolonial option eds. W. Mignolo and A. Escobar, 22-32. London: Routledge.

Radcliffe, S. 2017. Decolonising geographical knowledges. Transactions of the Institute of British Geographers 42 (3): 329-333.

Ribeiro, D. 2000. The Brazilian people. Gainesville: University Press of Florida.

Roberts, N. 2015. Freedom as marronage. Chicago: The University of Chicago Press.

Reclus, E. 1894. Nouvelle Géographie universelle, vol. 19. Paris: Hachette.

Rodrigues, D.V. 2008. Quando a forma altera o conteúdo: Abolição e reforma agrária, conflitos e conivências na territorialização do Estado brasileiro. Boletim DATALUTA, 6.

Schwarcz, L.M. 2013. Nem preto nem branco, muito pelo contrario. Cor e raça na sociabilidade brasileira. São Paulo: Claro Enigma.

Schwarcz, L.M. and Starling I. 2018. Brazil, a biography. London: Penguin Books.

Scott J.C. 1985. Weapons of the weak: everyday forms of peasant resistance. New Haven: Yale University press.

Shilliam, R. 2012. Redemption from development: Amartya Sen, Rastafari and promises of freedom. Postcolonial Studies 15 (3): 331-350.

Shilliam, R. 2015. The Black Pacific: anti-colonial struggles and oceanic connections. London: Bloomsbury.

Shilliam, R. 2017. Race and Revolution at Bwa Kayiman. Journal of International Studies 45 (3): 269-292.

F. Ferretti, 2019 "Decolonising the Northeast: subalterns, non-European heritages and radical geography in Pernambuco", Annals of the American Association of Geographers [early view] https://www.tandfonline.com/doi/full/10.1080/24694452.2018.1554423 
Silva, S.R. da. 2008. Negros na Mata Atlântica, territórios quilombolas e a conservação da natureza. Sao Paulo (USP): PhD Dissertation.

Slater, D. 1993. The geopolitical imagination and the enframing of development theory. Transactions of the Institute of British Geographers 18 (4): 419-437.

Souza, M.L. de. 2016. Lessons from praxis: Autonomy and spatiality in contemporary Latin American social movements. Antipode 48 (5): 1292-1316.

Spivak, G. 1988. Can the Subaltern speak? In Marxism and the interpretation of culture, eds.

C. Nelson and L. Grossberg, 271-313. Urbana: University of Illinois Press.

Stahler-Sholk, R., Vanden H. and M. Becker. 2014. Rethinking Latin American social movements: Radical action from below. London: Rowman \& Littlefield.

Stepan, N.L. 2000. Tropical Modernism: designing the tropical landscape. Singapore Journal of Tropical Geography 21(1): 76-91

Tendler S. 1994. Josué de Castro cidadão do mundo. Documentary https://www.youtube.com/watch?v=fQrwW1sjHyI

Viotto Pedrosa, B. 2017. A recepção da teoria dos polos de crescimento no Brasil. Terra Brasilis, 9: http://journals.openedition.org/terrabrasilis/2348

Zibechi, R. 2012. Territories in Resistance: A Cartography of Latin American Social Movements. Edinburgh: AK Press.

Ziegler J. 2013. Betting on hunger. Why the world still goes hungry. New York/London: The New Press.

\section{Author's biography}

Federico Ferretti received his PhD from the Universities of Bologna and Paris 1 PanthéonSorbonne in 2011. After research and teaching experiences in Italy, France, Switzerland and

F. Ferretti, 2019 "Decolonising the Northeast: subalterns, non-European heritages and radical geography in Pernambuco", Annals of the American Association of Geographers [early view] https://www.tandfonline.com/doi/full/10.1080/24694452.2018.1554423 
Brazil, he is now Associate Professor in the School of Geography at University College Dublin (UCD), Belfield - Dublin 4, Ireland. E-mail: federico.ferretti@ucd.ie. His research and teaching interests lie in philosophy and history of geography and on international circulation of geographical knowledge through critical, decolonial and anarchist approaches, with a special focus on Latin America and the Global South.

F. Ferretti, 2019 "Decolonising the Northeast: subalterns, non-European heritages and radical geography in Pernambuco", Annals of the American Association of Geographers [early view] https://www.tandfonline.com/doi/full/10.1080/24694452.2018.1554423 